\title{
Natural reforestation of Kuzbass dumps
}

\author{
Olga Klimova* and Andrei Kupriyanov \\ Federal Research Center of Coal and Coal Chemistry SB RAS, Leningradskiy prospect, 10, \\ Kemerovo, 650065, Russia
}

\begin{abstract}
We study the restoration of coal mining dumps through reforestation in the forest-steppe zone of Kuzbass. 3 main forest-forming species (Betula pendula, Pinus sylvestris and Populus tremula) and 11 accompanying tree species were involved in the formation of forest stands. The main forest-forming species was Betula pendula. The amount of renewal was found to be $10.7,3.1$ and 1.0 thousand $\mathrm{pcs} / \mathrm{ha}$ in sites with favourable, moderate favourable and unfavourable environmental conditions, respectively. The level of natural reforestation on dumps in the southern forest-steppe zone can be described as weak. The renewal of the Acer negundo invasion species was determined by a continuous drift of seeds on the dumps; however, its seedlings and young undergrowth did not reach a generative age.
\end{abstract}

\section{Introduction}

Reforestation is the process of restoring forest ecosystems in sites previously deforested due to natural or anthropogenic causes. Dump reforestation is an important criterion for the reclamation of ecosystems disturbed by mining [1]. Successful dump reforestation primarily depends on zoning, dump state and the location of nearby undisturbed ecosystems [2]. Although the restoration of vegetation cover on coal mining dumps in Kuzbass have been extensively studied [3], the problem of restoring waste dumps through reforestation remains to be elucidated. First of all, this concerns quantitative and qualitative indicators of undergrowth. In this research, we studied the forestation of dumps formed as a result coal open-pit mining in the southern forest-steppe ecoregion. The research objectives included the determination of the number and state of young undergrowth of woody plants on various parts of the dump relief, as well as the assessment of reforestation efficacy.

\section{Materials and Methods}

The research objects were the dumps of the Bachatsky, Vakhrushevsky and Krasnobrodsky coal mines located in the southern part of the forest-steppe zone of Kuzbass. This territory is characterised by a small amount of precipitation of $300-350 \mathrm{~mm}$ per year, the average annual temperature of $0.8-1.0{ }^{\circ} \mathrm{C}$ and the hydrothermal coefficient of $0.8-1.0$ [4].

\footnotetext{
* Corresponding author: olia_1983kem@mail.ru
} 
The main forest-forming species in the forest-steppe part of the south of Western Siberia are Betula pendula, Pinus sylvestris and Populus tremula. The accompanying species are trees and shrubs of the second story.

For quantitative counts of renewals and young forest undergrowth, a series of 50-200 plots $\left(1 \mathrm{~m}^{2}\right)$ were laid within an ecologically homogeneous area, where the species composition, quantity and age of the young forest undergrowth were determined. We took into account the renewal and young forest undergrowth aged 2-7 years with a height of up to $1.5 \mathrm{~m}$.

The counting results were assessed according to the scale of natural renewal by Nesterov [5]. The undergrowth was assessed according to two gradations: the main forestforming tree species (Populus tremula, Betula pendula and Pinus sylvestris) and accompanying species (tree species forming the second story of plantations).

According to the degree of ecological preference, the following habitats were identified: favourable, including terraced slopes, hollows between ridges, levelled areas and northern slopes up to $15^{\circ} \mathrm{C}$ ); moderately favourable, including slopes of the north-western exposure and the dump tops with a well-defined hilly-ridge relief; and unfavourable, including southern and southwestern slopes with a steepness of $15^{\circ} \mathrm{C}-20^{\circ} \mathrm{C}[3]$.

\section{Results and Discussion}

The largest amount $(26.1 \pm 5.5$ thousand pcs/ha) of renewal and forest undergrowth on the dumps of the Bachatsky coal mine was found in a site characterized by favourable conditions. The renewal of the main species was $21 \%$, and the fraction of accompanying species was 79\% (Table). In sites with favourable conditions, 6 accompanying species were observed. Acer negundo had the largest share (78.6\%), with Hippophaë rhamnoides ranking second (14.6\%). Under moderately favourable conditions, the total amount of renewal was 12.3 thousand $\mathrm{pcs} / \mathrm{ha}$. The share of the main forest-forming species was $94 \%$, while the share of accompanying species was only 6\%. Populus tremula and Betula pendula were among those mainly renewed (9.2 and 2.4 thousand pcs/ha, respectively). Pinus sylvestris was absent in the undergrowth. Under moderately favourable conditions, 4 species of accompanying species were found with the largest share of Lonicera tatarica (57.2\%). Under unfavourable conditions, the total amount of renewal was 9.4 thousand $\mathrm{pcs} / \mathrm{ha}$. The share of the main forest-forming species accounted for $16 \%$ of the renewal amount, the rest was related to the accompanying species. Among the main forest-forming species, the most abundant was Populus tremula -1.1 thousand pcs/ha. Under unfavourable conditions, 7 species of accompanying woody plants were found, with the largest share (55.6\%) of Hippophaë rhamnoides.

Of particular interest are a large number (20.7 thousand pcs/ha) of accompanying species observed under favourable conditions and their extremely small amount $(0.7$ thousand $\mathrm{pcs} / \mathrm{ha}$ ) under moderately favourable conditions. In addition, the undergrowth of Acer negundo was present in all variants, although its share decreased from 78.6 to $3.8 \%$ along with a change in conditions from favourable to unfavourable.

On the dumps of the Vakhrushevsky coal mine, the largest amount (14.9 thousand $\mathrm{pcs} / \mathrm{ha}$ ) of undergrowth was found in a site with favourable conditions. The renewal of the main species was $40 \%$, and the share of accompanying species was $60 \%$ (Table). Under favourable conditions, the amount of renewal for Pinus sylvestris was 0.25 thousand pcs/ha, for Betula pendula 2.9 thousand pcs/ha, and for Populus tremula 2.8 thousand pcs/ha (Table). Poplar and, to a lesser extent, Siberian mountain ash prevailed among the accompanying species under favourable conditions. Under moderately favourable conditions, the total amount of renewal was 10.7 thousand pcs/ha, with the main forestforming species accounting for $100 \%$. No undergrowth of accompanying species was 
found. Under unfavourable conditions, the total amount of renewal was 7.5 thousand $\mathrm{pcs} / \mathrm{ha}$. The share of the main forest-forming species accounted for $45.3 \%$ of the renewal. The accompanying species was the Acer negundo undergrowth (Table). Noteworthy, there was an almost complete absence of accompanying species under moderate and unfavourable conditions.

On the dumps of the Krasnobrodsky coal mine, the largest amount (27.2 thousand $\mathrm{pcs} / \mathrm{ha}$ on average) of undergrowth was found in a site with favourable conditions. The share of the main species was $80 \%$ of the total renewal (Table). Under favourable conditions, the amount of renewal of Pinus sylvestris was 0.15 thousand pcs/ha, Betula pendula 24.0 thousand $\mathrm{pcs} / \mathrm{ha}$ and Populus tremula 3.05 thousand $\mathrm{pcs} / \mathrm{ha}$ (Table). Under moderately favourable conditions, the total amount of renewal was 1.8 thousand $\mathrm{pcs} / \mathrm{ha}$. The share of the main forest-forming species accounted for $56 \%$. Under unfavourable conditions, the total amount of renewal was 1.4 thousand $\mathrm{pcs} / \mathrm{ha}$. The share of the main forest-forming species accounted for $28.6 \%$ of all the renewal. No pine undergrowth was found. A total of 4 accompanying species were found. The total number of accompanying species was 2.0 thousand pcs/ha under favourable conditions, 1.4 thousand pcs/ha under moderately favourable conditions and 1.0 thousand $\mathrm{pcs} / \mathrm{ha}$ under unfavourable conditions (Table). Among the accompanying species, Acer negundo had the largest share (97.0\%) under favourable conditions, Crataegus sanguinea (57.1\%) under moderately favourable conditions, and Crataegus sanguinea hawthorn and Acer negundo (40\% each) under unfavourable conditions.

Table. Renewal on dumps in the southern forest-steppe, thousand pcs/ha

\begin{tabular}{|c|c|c|c|}
\hline \multirow[t]{2}{*}{ Variants } & \multicolumn{3}{|c|}{ Forest conditions } \\
\hline & Favourable & $\begin{array}{l}\text { Moderately } \\
\text { favourable }\end{array}$ & Unfavourable \\
\hline \multicolumn{4}{|l|}{ Bachatsky coal mine } \\
\hline Repetitions & 100 & 100 & 100 \\
\hline \multicolumn{4}{|c|}{ Main forest-forming species } \\
\hline Pinus sylvestris L. & $0.1 \pm 0.1$ & 0 & 0 \\
\hline Betula pendula Roth & $5.1 \pm 2.1$ & $2.4 \pm 0.3$ & $0.4 \pm 0.3$ \\
\hline Populus tremula L. & $0.2 \pm 0.1$ & $9.2 \pm 1.3$ & $1.1 \pm 0.3$ \\
\hline Subtotal & $5.4 \pm 2.3$ & $11.6 \pm 1.3$ & $1.5 \pm 0.3$ \\
\hline \multicolumn{4}{|l|}{ Accompanying species } \\
\hline $\begin{array}{l}\text { Crataegus sanguinea } \\
\text { Pall. }\end{array}$ & 0 & $0.1 \pm 0.1$ & $1.0 \pm 0.3$ \\
\hline $\begin{array}{l}\text { Sambucus sibirica } \\
\text { Nakai. }\end{array}$ & $0.1 \pm 0.1$ & 0 & 0 \\
\hline Ulmus pumila $\mathrm{L}$. & $0.5 \pm 0.2$ & 0 & 0 \\
\hline Lonicera tatarica $\mathrm{L}$. & 0 & $0.4 \pm 0.1$ & $0.8 \pm 0.2$ \\
\hline Acer negundo L. & $16.3 \pm 2.71$ & $0.1 \pm 0.1$ & $0.3 \pm 0.10$ \\
\hline $\begin{array}{l}\text { Hippophaë } \\
\text { rhamnoides L. }\end{array}$ & $3.0 \pm 0.9$ & 0 & $4.4 \pm 1.6$ \\
\hline Swidina alba (L.) Opiz & $0.2 \pm 0.1$ & $0.1 \pm 0.1$ & $0.9 \pm 0.2$ \\
\hline Padus avium Mill. & $0.6 \pm 0.27$ & 0 & 0 \\
\hline Rosa acicularis Lindl. & 0 & 0 & $0.1 \pm 0.1$ \\
\hline $\begin{array}{l}\text { Malus baccata (L.) } \\
\text { Brokh. }\end{array}$ & 0 & 0 & $0.4 \pm 0.2$ \\
\hline Subtotal & $20.7 \pm 3.2$ & $0.7 \pm 0,4$ & $7.9 \pm 3.2$ \\
\hline Total & $26.1 \pm 5.5$ & $12.3 \pm 1.7$ & $9.4 \pm 1.2$ \\
\hline
\end{tabular}




\begin{tabular}{|c|c|c|c|}
\hline \multicolumn{4}{|l|}{ Vakhrushevsky coal mine } \\
\hline Repetitions & 100 & 200 & 100 \\
\hline \multicolumn{4}{|c|}{ Main forest-forming species } \\
\hline Pinus sylvestris L. & $0.25 \pm 0.11$ & 0 & 0 \\
\hline Betula pendula Roth & $2.9 \pm 0.85$ & $5.1 \pm 1.1$ & $2.2 \pm 0.6$ \\
\hline Populus tremula L. & $2.8 \pm 0.65$ & $5.6 \pm 1.0$ & $1.2 \pm 0.6$ \\
\hline Subtotal & $5.95 \pm 1.61$ & $10.7 \pm 2.1$ & $3.4 \pm 1.2$ \\
\hline \multicolumn{4}{|l|}{ Accompanying species } \\
\hline Acer negundo L. & 0 & 0 & $4.1 \pm 1.9$ \\
\hline Sorbus sibirica Hedl. & $1.2 \pm 0.4$ & 0 & 0 \\
\hline $\begin{array}{l}\text { Populus } x \text { sibirica G. } \\
\text { Krylov et Grigoriev ex } \\
\text { A. Skvortsov }\end{array}$ & $7.7 \pm 0.7$ & 0 & 0 \\
\hline Subtotal & $8.9 \pm 1.1$ & 0 & $4.1 \pm 1.9$ \\
\hline Total & $14.9 \pm 2.71$ & $10.7 \pm 2.1$ & $7.5 \pm 3.1$ \\
\hline \multicolumn{4}{|c|}{ Krasnobrodsky coal mine } \\
\hline Repetitions & 400 & 50 & 50 \\
\hline \multicolumn{4}{|c|}{ Main forest-forming species } \\
\hline Betula pendula Roth & $24.0 \pm 4.57$ & $1.8 \pm 0.43$ & $0.4 \pm 0.19$ \\
\hline Pinus sylvestris L. & $0.15 \pm 0.05$ & 0 & 0 \\
\hline Populus tremula L. & $3.05 \pm 1.05$ & 0 & 0 \\
\hline Subtotal & $27.2 \pm 5.67$ & $1.8 \pm 0.43$ & $0.4 \pm 0.19$ \\
\hline \multicolumn{4}{|l|}{ Accompanying species } \\
\hline Acer negundo L. & $6.1 \pm 1.81$ & $0.6 \pm 0.23$ & $0.4 \pm 0.19$ \\
\hline $\begin{array}{l}\text { Crataegus sanguinea } \\
\text { Pall. }\end{array}$ & $0.1 \pm 0.1$ & $0.8 \pm 0.34$ & $0.4 \pm 0.19$ \\
\hline Padus avium Mill. & 0 & 0 & $0.2 \pm 0.14$ \\
\hline Salix cinerea L. & $0.1 \pm 0.1$ & 0 & 0 \\
\hline Subtotal & $6.3 \pm 2.01$ & $1.4 \pm 0.28$ & $1.0 \pm 0.19$ \\
\hline Total & $33.5 \pm 7.68$ & 3.2 & 1.4 \\
\hline
\end{tabular}

In the forest-steppe zone, Betula pendula is the main forest-forming species: its regeneration under favourable conditions exceeds 50 thousand pcs/ha providing sustainable reforestation [5]. On coal mining dumps in the southern forest-steppe zone, 10.7, 3.1 and 1.0 thousand $\mathrm{pcs} / \mathrm{ha}$ of young undergrowth are formed in the areas with favourable, moderate favourable and unfavourable environmental conditions, respectively. According to the Nesterov scale, the level of natural reforestation on dumps in the southern foreststeppe can be described as weak. However, it should be noted that this scale has been developed for assessing the renewal under natural conditions, thus being hardly applicable to dumps. L.P. Barannik, who studied reforestation on dumps in the mountain taiga subzone, believes that forests on overburden dumps perform a protective, rather than operational, function. Therefore, reforestation can be considered sufficient (satisfactory) at 3-4 thousand $\mathrm{pcs} / \mathrm{ha}$ of self-seeding deciduous species at the age of 5-10 years and 0.6-1.5 thousand pcs/ha of self-seeding species at the age of 15-20 years [2]. Hence, the renewal of Betula pendula on dumps can be considered satisfactory in almost all variants of the southern forest-steppe. Two species, Acer negundo and Ulmus pumila, are invasive and included in the Black Book of Siberia [6].

\section{Conclusion}


The main forest-forming species on coal mining dumps in the southern forest-steppe are Betula pendula, Pinus sylvestris, and Populus tremula. The accompanying species are Acer negundo, Crataegus sanguinea, Hippophaë rhamnoides, Lonicera tatarica, Malus baccata, Padus avium, Rosa acicularis, Salix cinerea, Sambucus sibirica, Swidina alba and Ulmus pumila. A more successful reforestation is achieved under favourable environmental conditions: in depressions, on northern slopes with a steepness of less than $15^{\circ}$ and in flat areas with a well-defined microrelief. The renewal of birch in general can be considered satisfactory on almost all dumps in the southern forest-steppe of the Kemerovo region. The abundance of the renewal of the Acer negundo invasive species is maintained by a continuous drift of seeds to dumps. Acer negundo is a nitrophilous plant; therefore, most seedlings and young undergrowth die before reaching a generative age.

The work was carried out within the framework of the state assignment of the Federal Research Center of Coal and Coal Chemistry SB RAS (project no. 0286-2021-0010).

\section{References}

1. A.N. Kupriyanov, Yu.A. Manakov, L.P. Barannik, Restoration of ecosystems on the dumps of the mining industry of Kuzbass (Academic publishing house "Geo": Novosibirsk, 2010)

2. L.P. Barannik, Bioecological principles of forest reclamation (Nauka: Novosibirsk, 1988)

3. Yu.A. Manakov, T.O. Strelnikova, A.N. Kupriyanov, Formation of vegetation cover in the technogenic landscapes of Kuzbass (Publishing house of the SB RAS: Novosibirsk, 2011)

4. A.P. Shimanyuk, Natural renewal in concentric felling areas (Publishing house of RAS: Moscow, 1955)

5. A.P. Shimanyuk, Pine forests of Siberia and the Far East (Publishing house of RAS: Moscow, 1962)

6. The Black Book of the Flora of Siberia (Academic publishing house "Geo": Novosibirsk, 2016) 